\title{
Legal Aspects of Remote Trial
}

\author{
Vladyslav Yamkovyi ${ }^{1 *}$, Oksana Telychko ${ }^{I}$, Iryna Mima $^{l}$, and Nina Ivaniuk ${ }^{l}$ \\ ${ }^{1}$ State University of Economics and Technology, 50005, Kryvyi Rih, Ukraine
}

\begin{abstract}
The introduction of new technologies, as well as digital is a new logical stage in the development of society, affecting all areas of humanity, including legal. The digitalization of society is becoming the most important factor in economic growth and is a modern trend in the development of any country in the world. Ukraine is no exception to this list, as it has chosen to bring its national legal system closer to the European Union's legal system and international legal standards, which is a complex and lengthy process. Unfortunately, so far there are no generally accepted and harmonized definitions and legal definitions for the legal regulation of introducing digital technologies in the Ukrainian legal system. This necessitates a more thorough study of implementing digital technologies in the legal field. This article is devoted to the problems concerning legal regulation of remote court proceedings by videoconference, which is designed to simplify access to justice and lead to savings in material and procedural means in court proceedings. The purpose of this article is to identify problematic issues regarding legal regulation of distance litigation in Ukraine and to propose mechanisms for its improvement as well as to harmonize it with international legal standards.
\end{abstract}

\section{Introduction}

Electronic technologies have become an integral part of the entire society life, the basis for building information flows at the local, national and international levels around the world, including work of the judiciary in Ukraine.

The use of electronic technologies in the administration of justice in Ukraine was enshrined in the Law of Ukraine "On the Judiciary and the Status of Judicial Bodies" № 2453-VI of 07.07.2010 [1], so amendments were made to all procedural codes for the introduction of automated document management in courts. Informative and impartial distribution of cases between courts, providing individuals and legal entities with information on the status of cases in which they participate.

Subsequently, in 2011 the Law of Ukraine "On Amendments to Certain Legislative Acts of Ukraine in Connection with the Ratification of the Second Additional Protocol to the European Convention on Mutual Assistance in Criminal Matters" №3529-VI of 16.06.2011 [2] in force at that time the procedural code of Ukraine [3] was supplemented by Article 85-3 "Application of telephone conference and videoconference during the investigative action". This provision provided that in case it is impossible for participants of investigative or other procedural action to appear at the body of inquiry, investigator, prosecutor or in the court at the place of proceedings as well as in case of the need to ensure the safety of people involved in criminal proceedings or other reasonable grounds, investigative or procedural action with their participation may be carried out by telephone or video conference. A telephone or video conference was to be conducted on behalf of an inquiry body, investigator, prosecutor or court and could be used during the interrogation of a witness, expert, suspect, accused and defendant, face-to-face, identification, reproduction of the situation and circumstances of the event.

With the repeal of the old CPC of Ukraine and on 13.04.2012 a new version adoption of the Criminal Procedure Code of Ukraine [4] was introduced by Art. 336 entitled "Conducting procedural actions by videoconference during court proceedings", which stipulated that court proceedings may be carried out by videoconference during broadcasts from another room including those located outside the court premises (remote court proceedings). The decision to conduct remote court proceedings is made by the court on its own initiative or at the request of a party or other participants in criminal proceedings. If the party to the criminal proceedings or the victim objects to implementing remote court proceedings, the court may decide to carry it out only by a reasoned decision justifying the decision taken in it. The court does not have the right to make a decision on remote court proceedings in which the accused is outside the court premises, if he or she objects. The technical means and technologies used in remote court proceedings must ensure the proper quality of image and sound, compliance with the principle of publicity and openness of court proceedings as well as information security. The course and results of procedural actions carried out in the mode of videoconference are recorded by means of video recording technical means. A protected person may be questioned by videoconference with changes in appearance and voice that are unrecognizable. 
Subsequently, the Law of Ukraine "On Amendments to Certain Legislative Acts of Ukraine Concerning Participation in a Court Conference by Videoconference" № 5041-VI of 04.07.2012 [5] relevant amendments to the possibility of holding a court hearing by videoconference were introduced into the Commercial Procedure Code of Ukraine (hereinafter - CPC), the Civil Procedure Code of Ukraine (hereinafter - CPC) and the Administrative Judicial Procedure Code of Ukraine (hereinafter AJPC). These codes were supplemented by articles entitled "Participation in a court hearing by videoconference" of similar content, which provided that the court on its own initiative or at the request of a party or other party to the proceedings may decide to participate in a court hearing by videoconference. However, such participation in a court hearing by videoconference of a party or other party to the proceedings could necessarily take place only in the premises of another court, where it was necessary to ensure a videoconference.

In 2013, the project "Electronic Court" was launched, which continued to spread the use of new technologies and informatization of the Ukrainian judiciary.

According to the Strategy for the Reform of the Court Organization, Judiciary and Related Legal Institutions for 2015-2020, adopted by the Presidential Decree of Ukraine dated 20.05.2015 № 276/2015, one of the main judicial reform areas is to ensure the widespread use of information systems (IS)for providing greater number of e-justice services; to create electronic management in information systems courts, in particular to introduce full-fledged electronic systems, including electronic document management systems, and case tracking (to higher instances), electronic notifications, electronic calls, electronic cases (in some cases), electronic payments, audio and video recording of meetings [6].

In addition, on December 15, 2017, the new Commercial Procedure Code of Ukraine, the Civil Procedure Code of Ukraine and the Administrative Judicial Procedure Code of Ukraine came into force, which provides for the introduction of the Unified Judicial Information and Telecommunication System (hereinafter - UJITS), the operation of which should begin 90 days after publication by the State Judicial Administration of Ukraine in the newspaper " The Voice Of Ukraine "and on the web portal of the judiciary the announcement on the establishment and maintenance of the UJITS, which has been postponed for more than three years. Unfortunately, until now, participation in the court hearing by videoconference within the court premises is carried out only with the help of technical means operating in the courts.

This shows that at the state level, considerable attention is paid to ensuring the conduct of court proceedings remotely in order to facilitate access to justice, but in the absence of the functioning of the UJITS, these opportunities are used to a limited extent.

\section{Analysis of foreign experience and international practice in the field of remote litigation}

The use of videoconferencing during court hearings has become a common practice throughout the world. Therefore, the study of foreign experience in this regard is an integral part of the study on the improvement of national legislation. The analysis of foreign and international legal norms on this issue becomes especially relevant.

The Convention for the Protection of Human Rights and Fundamental Freedoms of 1950, better known as the European Convention on Human Rights, stipulates in Article 6, paragraph 1, that everyone in determining his or her civil rights and obligations or in bringing any criminal charges against him or her, has the right to a fair and open hearing within a reasonable time by an independent and impartial tribunal established by law [7].

The general right to judicial protection is also enshrined in the International Convention on the Elimination of All Forms of Racial Discrimination 1965 (Articles 5, 6) [8]; Convention on the Rights of the Child 1989 (Articles 12, 37, 40) [9]; UN General Assembly resolution No.40/33 [10].

A number of provisions on ensuring simplified access of citizens to effective justice and speeding up the consideration of cases are enshrined in the regulations of the European Council , including:

- Recommendation No.R (81) 7. Of The Ministers Committee To Member States. On Measures Facilitating Access To Justice (Adopted by the Committee of Ministers on 14 May 1981 at its 68th Session), which sets out principles and provisions for simplifying and expediting judicial proceedings [11];

- Recommendation No. R (84) 5. Of The Committee Of Ministers To Member States On The Principles Of Civil Procedure Designed To Improve The Functioning Of Justicel (Adopted by the Committee of Ministers on 28 February 1984 at the 367th meeting of the Ministers' Deputies), according to which judicial authorities must have the most up-todate technical means to enable them to administer justice in the most efficient way, in particular by facilitating access to various sources of law and by speeding up the administration of justice [12];

- Recommendation No. R (95) 13. Of The Committee Of Ministers To Member States Concerning Problems Of Criminal Procedural Law Connected With Information Technology (Adopted by the Committee of Ministers on 11 September 1995 at the 543rd meeting of the Ministers' Deputies), which established that information on case law in all areas of law and in all regions should be disseminated through one or more automated systems, which, in turn, would facilitate the provision of online court hearings [13].

These recommendations are general in justifying the need to introduce provisions for conducting court hearings online, the feasibility of their holding as well.

According to Opinion № (2011) 14 of the Consultative Council of European Judges "Justice and information technologies (IT)", IT should be a tool or 
means to improve the administration of justice, facilitate user access to courts and strengthen the guarantees established by Art. 6 of the European Convention on Human Rights, access to justice, impartiality, independence of the judge, fairness and reasonable time for consideration of the case. Video conferencing can facilitate security hearings and the taking of testimony from witnesses and experts. Particular attention should be paid to ensuring that conference calls and the taking of evidence in this way do not infringe on the guaranteed right of defense, encourage the use of IT to strengthen the role of the judiciary in upholding the rule of law in democracies; IT should not interfere with the authority of a judge and undermine the guidelines set out in Art.6 of European Convention on Human Rights [14].

According to $\mathrm{Zub} \mathrm{O}$. the introduction of video conferencing in the American judicial system, called "telejustice", has allowed not only to reduce the cost of maintaining the judiciary, but also to speed up the trial as a whole. According to the Pew Charitable Foundation, which conducted a study on the effectiveness of introducing telejustice in the United States, consideration of cases, which were usually heard for about 120 days, now took no more than 10 days, which was caused by the lack of need for personal (in-person) appearance of the participants in the courtroom. Money savings from the use of teleconferencing in US criminal justice, such as the Philadelphia Pennsylvania Court Court, amounted to \$ 550,000 per month in 2011 because prisoners were not taken from custody or imprisonment to court, but used videoconferencing connection. At the same time, providing courtrooms with equipment needed for video conferencing in Pennsylvania cost \$ 4.2 million [15].

Videoconferencing has also become an effective tool that has facilitated and accelerated cross-border litigation in European Union countries. In the context of European e-Justice, video conferencing has been introduced in a new concept - interstate video conferencing.

In Finland, for example, there are several types of video conferencing equipment: (a) for court hearings, a complete set, with a high resolution that provides highquality recording and screen images; (b) for preliminary hearings, a separate set for conference rooms; (c) for hearing witnesses, a basic set of terminal, camera and microphone.

Under the rules of civil procedure in England, the court may order hearings of any dispute or part thereof to be heard by videoconference. If one of the parties objects to the application of the remote trial or the right to be heard or the right to be notified of the time and place of the trial is violated as a result of the videoconference, the videoconference shall not apply [16].

The German Code of Civil Procedure provides for open-air hearings using video conferencing systems. There are two types of such listeners: remote participation of the parties and remote reception of the shown witnesses. The hearing in the case of remote participation of a party is possible only with the consent of both parties by videoconference. This hearing should be accompanied by the simultaneous mutual transmission of image and sound from one place to another, and vice versa. The second case provides that in agreement with both parties the court may find a court decision on how to allow a witness, an expert to testify from other places. But this practice of using new technologies is a quicker exception to the rules of the court hearing, and therefore preference is given to the traditional hearing for the participation of all people in the courtroom $[17,22]$.

A slightly different approach to the use of video conferencing exists in Japan, where the installation of video conferencing systems is witness-oriented. According to Art.204 of the Civil Procedure Code of Japan, the court may remotely interrogate a witness using a method that provides mutual exchange of video and audio information, due to the age or psychological state of the witness, or if there are reasons to believe that direct participation in the hearing will cause psychological suffering to the interrogated or put pressure on the witness [17, p. 22-23]

This suggests that despite the differences between different legal systems, video conferencing and remote justice have played an important role in ensuring simplified access to justice for individuals.

\section{Analysis of the state of scientific research}

The issue of using videoconferencing in the judiciary in the Ukrainian scientific community has been considered only partially, in the context of research on the use of information technology in the judiciary. The vast majority of authors in their works pay considerable attention to the definition of "videoconferencing" and the legal regulation of its conduct. The vast majority of works concerns criminal proceedings.

Sizonenko A. defines videoconferencing as a twoway video, audio communication between two points, the distance between which does not matter, in real time (excluding time zones), in one of which there are persons conducting and participating in the investigation, and in another - those with whom the procedural action is carried out [18, p. 96]. However, such a definition artificially narrowed the scope of videoconferencing only to cases of investigative actions.

On the other hand, Smirnov M. defined videoconferencing as a special procedure during which communication in the form of audio and video information exchange between remote participants of the investigative action takes place at a distance (remotely), but in real time [19, p. 97].

An analysis of international legal acts and foreign scientific publications shows that in the law enforcement practice of most UN member states the terms "videolink" (or "video link"), "videoconference" (or "video conference") are used to refer to remote litigation; "Videoconferencing" (or "video-conference link") [22]. 
The Ukrainian legislation actually borrows this terminology, but currently there is no single approach to its definition and disclosure. Thus, in criminal proceedings, the term "remote court proceedings" is used, which is absent in other court proceedings. At the legislative level, the concept of "videoconferencing" is not disclosed, there are no terms "videoconferencing system", "technical means of video recording", "videophonogram", neither procedure for making and storing copies of videophonograms, nor the procedure for making archival copies to create working copies in case of their insufficiency, damage or destruction is regulated. This greatly complicates the use of video conferencing.

However, according to Bogunov $\mathrm{V}$. the introduction of the protection possibility and their rights exercise in court by videoconference is justified by such factors as saving time and money of participants in the process, which are spent on travel (or delivery) to court [23].

Garievskaya M. considers that the advantages of holding court hearings by videoconference also include the ability to speed up the trial and save money for both the judiciary (for example, to send summonses to the hearing) and for participants in the process (including business trips) [23, p. 60]

Among the so-called "disadvantages" or "difficulties" of conducting court hearings by video conference Ozernyuk G. highlights the following: the need for technical equipment of courts with special facilities for organizing a court hearing by videoconference, the availability of high-speed Internet; the need for awareness of the participants of the process with the latest technologies and the ability to use them; legislative unresolved issues on participation in the trial by videoconference, in particular, outside the courtroom; loss of the verbal side of communication with the participants of the process with the participation of an interpreter, etc. [25, p.27].

Among the so-called "disadvantages" or "difficulties" of conducting court hearings by video conference Ozernyuk G. highlights the following: the need for technical equipment of courts with special facilities for organizing a court hearing by videoconference, the availability of high-speed Internet; the need for awareness of the participants in the process with the latest technologies and the ability to use them; legislative unresolved issues on participation in the trial by videoconference, in particular, outside the courtroom; loss of the verbal side of communication with the participants of the process with the participation of an interpreter, etc. [25, p.27].

According to Kravtsova T., Kornienko M. the advantages of conducting videoconferences outside the court include ensuring social isolation, security of participants, judges and court staff, and among the disadvantages - new opportunities for abuse of procedural rights by unscrupulous participants [26].

After analyzing these views, it should be noted that the videoconferencing system is undoubtedly an important innovative breakthrough in the domestic justice system, but has not found proper application in practice due to a number of difficulties and legislative gaps, one of which is delays in the start of UJITS. However, a more complete legislative settlement can remedy this situation.

\section{The current state of regulation and ways to improve it}

Normative legal acts, which at the national level enshrine the possibility of participation in court proceedings by videoconference and the exercise of the right to justice, are primary regarding the rights of participants in court proceedings to participate in remote proceedings, so their improvement is an important aspect.

Today, all procedural codes, without exception, stipulate that, in accordance with the law, the UJITS ensures the recording of the trial and the participation of the participants in the trial in a court session by videoconference. Persons who have registered official e-mail addresses in the UJITS may perform procedural actions in electronic form only through the Unified Judicial Information and Telecommunication System, using their own electronic digital signature, equated to a handwritten signature in accordance with the Law of Ukraine "On Electronic Digital Signature" (hereinafter - EDS Law) [27], unless otherwise provided by the relevant procedural code. Peculiarities of the use of electronic digital signature in UJITS are determined by the Regulations on UJITS. However, the relevant regulations have not been adopted for more than three years.

And therefore it is necessary to be guided by provisions of codes. Thus, the possibility of participating in a court hearing by videoconference is provided by Art.197 of the Civil Procedure Code [28], Art. 212 of the Commercial Procedure Code of Ukraine [29], Art.195 of the Administrative Judicial Procedure Code of Ukraine [30], which stipulates that the parties to the case participate in the hearing by videoconference outside the courtroom using their own technical means and electronic digital signature in accordance with the requirements of the Regulations on UJITS.

In addition, in connection with the adoption of Regulation (Eu) No 910/2014 of the European Parliament and of the Council of 23 July 2014 on electronic identification and trust services for electronic transactions in the internal market and repealing Directive 1999/93 / EC [31] The EDS Law has expired and has been replaced by the Law of Ukraine "On Electronic Trust Services" [32], and therefore the provisions of the procedural codes regarding the identification of persons in the UJITS should be brought in line with current legislation on electronic trust services.

Therefore, prior to the introduction of the UJITS and legislative changes, court hearings may be held by videoconference only if the party to the proceedings is in the courtroom closest to his or her place of residence and equipped with special technical means. 
The situation has changed in the context of a global pandemic, as a result of which the Code of Civil Procedure, the Commercial Procedure Code and the Administrative Judicial Procedure Code of Ukraine were amended, according to which during the quarantine established by the Ministers' Cabinet of Ukraine to prevent the spread of coronavirus (COVID19), the parties to the case may participate in the court session by videoconference outside the court premises using their own technical means. The confirmation of the person involved in the case is carried out using an electronic signature, and if the person does not have such a signature, in the manner prescribed by the Law of Ukraine "On the Unified State Demographic Register and documents confirming citizenship of Ukraine, identity or special status" [33] or State Judicial Administration of Ukraine.

Based on this, the State Judicial Administration of Ukraine by order of 23.04.2020 № 196 approved a new version of the Procedure for working with technical means of videoconferencing during the hearing in administrative, civil and commercial proceedings with the participation of the parties outside the court [34]. This has greatly simplified the participation of individuals in remote litigation. This Order stipulates that in order to participate in a court hearing by videoconference, the party to the case must:

- pre-register using your own electronic signature in the Video Conferencing System (hereinafter - the System) at the link on the official web portal of the judiciary of Ukraine vkz.court.gov.ua or with the help of other available to the court and litigants means to ensure court hearings by videoconference and meet the requirements of the law;

- check his / her own technical means for compliance with the technical requirements defined for work with the System selected for videoconferencing;

- if the participant does not have an electronic signature (or the System does not allow registration using an electronic signature), he/she must pre-register in the System using a login and password or using other means of registration provided by the selected System. In this case, the decision on the possibility to confirm the identity of the party to the case, which does not have an electronic signature as well as the decision on choosing the System to be used for court hearings by videoconference,

- submit an application for participation in the court hearing by videoconference outside the court premises not later than five days before the court hearing, obligatorily stating: the name of the court; court number; the date and time of the court hearing in which the participant wishes to participate in the videoconference; your last name, first name and patronymic; your status in a court case; the e-mail address used by them for registration in the System; the name of the system proposed for video conferencing; court telephone number; a note on the presence or absence of an electronic signature.

The application is submitted to the court and sent to other participants in the case in the manner prescribed by procedural law, by permitted means of communication.
These provisions have temporarily but not definitively resolved the issue of unresolved participation in court hearings by videoconference outside the court premises prior to the implementation of the UJITS Regulation, but the need for its adoption at the legislative level has not disappeared. Therefore, the legal regulation of remote litigation needs further improvement.

\section{Conclusion}

As a result of the research, the following conclusions can be drawn:

1. The advantages of remote court proceedings are the acceleration of the trial, saving time and money for both participants in the process and the state in the face of the judiciary, ensuring social isolation in a global pandemic, ensuring the safety of litigants.

2. In order to overcome the difficulties associated with conducting videoconference hearings, it is necessary to provide courts with adequate technical equipment of the premises in sufficient numbers to organize videoconferencing trials and with uninterrupted high-speed Internet; to introduce clear and effective mechanisms for the legal regulation of all court proceedings; it is essential to ensure the functioning of the Unified Judicial Information and Telecommunication System as soon as possible.

3. Bring the provisions of the procedural codes regarding the identification of persons in the UJITS and the videoconferencing system by means of an electronic digital signature in line with the current legislation on electronic trust services.

4. In order to unify the terminology in the legal regulation field of remote court proceedings and the use of videoconferencing to establish at the legislative level the following terms and concepts:

Remote litigation is litigation by videoconference during a broadcast from another room, including one located outside the courtroom.

Video conferencing is a telecommunication technology of interactive interaction of two or more remote participants in court proceedings with the possibility of exchanging audio and video information in real time.

Video conferencing system is a set of hardware and software (according to the link on the official web portal of the judiciary of Ukraine vkz.court.gov.ua) or other means available to the court and litigants, providing court hearings by video conferencing and meet the requirements of the law.

Video recording technical means of the course and results of procedural actions are a set of software and hardware and devices that provide proper audio and video recording, storage, copying (duplication) and use of information that reflects the process of video conferencing.

Video phonogram is video and audio recording, which is formed directly during the video conference and recorded by technical means of video recording and is the source material for making working and archival copies. 
Archival copy of a video phonogram is a recording of a video phonogram copy from technical means on a video recording medium, which has the status of the original and is intended for long-term storage. An archival copy can be used to create working copies in case of their insufficiency, damage, destruction, etc.

Working copy of the video phonogram is a recording a copy of the video phonogram from the technical means of video recording on the video recording medium, which has the status of the original and is attached to the case file.

A video medium of videoconferencing is a disk for laser reading systems on which a video phonogram is recorded, which is an appendix to the minutes of the court hearing.

5. The procedure for working with technical means of videoconferencing during a court hearing, the procedure for holding a court hearing by videoconference, the procedure for making and storing a technical record and its copies shall be subject to determination at the legislative level; the procedure for submitting an application for participation in a court hearing by videoconference, the procedure for the distribution of responsibilities for the implementation of organizational measures related to the functioning of the videoconferencing system; ensuring the possibility of cross-border proceedings in different countries as well as participation in the court hearing by videoconference of the participants in the process, who are abroad.

\section{References}

1. Law of Ukraine № 2453-VI of July, 07, 2010, «On the Judiciary and the Status of Judges», https://zakon.rada.gov.ua/laws/show/140219\#Text,

2. Law of Ukraine №3529-VI of June, 06, 2011, «On Amendments to Certain Legislative Acts of Ukraine in Connection with the Ratification of the Second Additional Protocol to the European Convention on Mutual Assistance in Criminal Matters», https://zakon.rada.gov.ua/laws/show/352917\#Text

3. Law of Ukraine № 1001-05 of December, 31, 1960, «Criminal Procedure Code of Ukraine, https://zakon.rada.gov.ua/laws/show/100105\#Text

4. Law of Ukraine № 4651-VI of April, 13, 2012, «Criminal Procedure Code of Ukraine», https://zakon.rada.gov.ua/laws/show/465117\#Text

5. Law of Ukraine № 5041-VI of July, 04, 2012, «On Amendments to Certain Legislative Acts of Ukraine Concerning Participation in a Court Session by Videoconference», https://zakon.rada.gov.ua/laws/show/504117\#Text

6. Decree of the President of Ukraine № 276/2015 of May, 20, 2015, «Strategy for reforming the judiciary, the judiciary and related legal institutions for 2015-2020», http://zakon2.rada.gov.ua/laws/show/276/2015/pri nt1509894126567793

7. The Convention for the Protection of Human Rights and Fundamental Freedoms https://www.echr.coe.int/Documents/Convention ENG.pdf

8. International Convention on the Elimination of All Forms of Racial Discrimination, Adopted and opened for signature and ratification by General Assembly resolution 2106 (XX) of 21 December 1965 entry into force 4 January 1969, in accordance with Article 19 https://www.ohchr.org/en/professionalinterest/pag es/cerd.aspx

9. Convention on the Rights of the Child, Adopted and opened for signature, ratification and accession by General Assembly resolution 44/25 of 20 November 1989, Entry into force 2 September 1990, in accordance with article 49 https://web.archive.org/web/20100611182141/http ://www2.ohchr.org/english/law/crc.htm

10. United Nations Standard Minimum Rules for the Administration of Juvenile Justice ("The Beijing Rules") Adopted by General Assembly resolution 40/33 of 29 November 1985 , https://www.ohchr.org/documents/professionalinte rest/beijingrules.pdf

11. Recommendation No. R (81) 7. Of The Committee Of Ministers To Member States. On Measures Facilitating Access To Justice. (Adopted by the Committee of Ministers on 14 May 1981 at its 68th Session), https://rm.coe.int/168050e 7e4

12. Recommendation No. R (84) 5 Of The Committee Of Ministers To Member States On The Principles Of Civil Procedure Designed To Improve The Functioning Of Justicel (Adopted by the Committee of Ministers on 28 February 1984 at the 367th meeting of the Ministers' Deputies) https://rm.coe.int/CoERMPublicCommonSearchSe rvices/DisplayDCTMContent?documentId=09000 016804e19b1

13. Recommendation No. R (95) 13 Of The Committee Of Ministers To Member States Concerning Problems Of Criminal Procedural Law Connected With Information Technology (Adopted by the Committee of Ministers on 11 September 1995 at the 543rd meeting of the Ministers' Deputies), https://rm.coe.int/16804f6e76

14. Opinion No.(2011)14 of the Consultative Council Of European Judges «Justice and information technologies (IT)» Adopted by the CCJE at its 12th plenary meeting (Strasbourg, 7-9 November 2011), https://rm.coe.int/168074816b

15. O. Yu. Zub, Videoconference as a means of simplification of civil proceedings, Bulletin of $V N$ Karazin Kharkiv National University. Series: Right, 17, (2014), http://nbuv.gov

16. Sir Brahmaiah Maroju. Video Conferencing in Judicial Proceedings - An Innovative Practice // Centre for Innovations in Public Systems, of May, 2020, http://www.cips.org.in/public-sector26systemsgovernmentinnovations/documents/vide 
o-conferencing-injudicialproceedings-aninnovative-practice.pdf.

17. Miklos Kengyel; Zoltan Nemessanyi. Electronic technology and civil procedure : new paths to justice from around the world, 329, (2012). http://books.google.ru

18. Syzonenko A. Video communication as a means of investigative actions outside Ukraine, Law of Ukraine. 3, (2003).

19. Smirnov MI Features of mutual legal assistance in criminal cases using the method of videoconferencing: dis...PhD, 268, (2005).

20. Pashkovsky, MI Videoconference in criminal proceedings, Legal life of modern Ukraine: International scientific conference of teaching and graduate students (Odessa, May, 21-22, (2010)

21. Bortun M. Current issues of interrogation by video conference, Bulletin of the National Academy of Prosecutors of Ukraine, 1, 34, (2014).

22. Chernychenko I. The concept and procedural-legal essence of videoconference in the criminal proceedings of Ukraine, Visnyk of Lviv National University. The series is legal, 59, (2014)

23. Bogunov V. Videoconferencing will allow participants to save time and money, Law and Business, 35, (2012).

24.Garievskaya MB Videoconference in civil proceedings, Private law and entrepreneurship, 14, (2015)..

25. Ozernyuk GV Legal regulation of court hearings by videoconference under the laws of the European Union, 1, (2020), http://nbuv.gov.ua/UJRN/srjusc_2020_1_6

26.Kravtsova T., Kornienko M. Court hearings by videoconference, Ukrainian lawyer, 4-5, (2020). https://www.asterslaw.com/ru/press_center/publica tions/court_hearings_via_vidvideoconferen_ in_ukraine/

27. Law of Ukraine № 852-IV of May, 22, 2003, «About electronic digital signature», https://zakon.rada.gov.ua/laws/show/852-15\#Text

28. Law of Ukraine № 1798-XII of November 6, 1991, «Commercial Procedural Code of Ukraine», https://zakon.rada.gov.ua/laws/show/179812\#Text

29. Law of Ukraine № 1618-IV of March, 18, 2004, « Civil Procedure Code of Ukraine», http://zakon5. rada.gov.ua/laws/show/1618-15

30. Law of Ukraine № 2747-IV of July, 6, 2005, «Code of Administrative Procedure of Ukraine», https://zakon.rada.gov.ua/laws/show/274715\#Text

31. Regulation (Eu) No 910/2014 Of The European Parliament And Of The Council of 23 July 2014 on electronic identification and trust services for electronic transactions in the internal market and repealing Directive 1999/93/EC, https://ec.europa.eu/futurium/en/system/files/ged/e idas_regulation.pdf
32. Law of Ukraine № 2155-VIII of October, 05, 2017, «About electronic trust services», https://zakon.rada.gov.ua/laws/show/2155$19 \#$ n534

33. Law of Ukraine № 5492-VI of November, 20, 2012, «About the Unified State Demographic Register and documents confirming the citizenship of Ukraine, identity or special status», https://zakon.rada.gov.ua/laws/show/5492$17 \#$ Text

34. Order of the State Judicial Administration of Ukraine № 196 of April, 23, 2020, «About modification of the Order of work with technical means of videoconferencing during court session in administrative, civil and economic processes with participation of the parties out of court premises», https://zakon.rada.gov.ua/rada/show/v019675020\#Text 